\title{
MINERALE GEME ASOCIATE GENETIC OFIOLITELOR MEZOZOICE ŞI GHEIZERITELOR NEOGENE, DIN MUNTiII APUSENI DE SUD
}

\author{
IOAN MÂRZA ${ }^{1}$, CIPRIAN CONSTANTINA ${ }^{2}$
}

\begin{abstract}
The paper studies the geological formations of the Geoagiu- Hărțăgani- Vălişoara- Brad region (Southern Apuseni Mountains) focusing on the content in gems minerals. Based on the field and laboratory reasearch, several perimeters of geological interest have been identified: Luncoiu Valley- Lunga Valley, Vălişoara Valley- Orăzii Valley, Baița-Crăciuneşti, Hărțăgani and Sanatoriu (Brad). Geologically, the minerals of gem quality (quartz, chalcedony, jasper) and they associate genetically and spatially with ophiolites, with the exception of the Brad silicolite- gems which represent geyserites generated by the neogene volcanism.
\end{abstract}

Key words: gem minerals (quart, chalcedony), gems rocks (jasps, geyserites), Southern Apuseni Mountains.

Investigațiile cu scop gemologic asupra regiunii încadrate de văile Geoagiu în est şi Vălişoara-Luncoiu în vest, efectuate din partea Institutului de Gemologie (Universitatea Babeş-Bolyai, Cluj-Napoca) au surprins câteva sectoare de interes în contextul formațiunilor geologice gazdă, pe care le prezentăm în continuare.

Informații geologice ample sau lapidare asupra regiunii la care ne referim sunt furnizate de Giuşcă et al. (1963); lanovici et al. (1969, 1976); Cioflica et al. (1981); Savu, (1980, 1983); Ghiurcă, (1981); Săndulescu, (1984); Mârza et al. (1989, 199133); Balintoni, (1997); Ghergari Lucreția şi lonescu Corina (1999) etc.

Aspecte geologice

1 Universitatea Babeş-Bolyai, Facultatea de Biologie-Geologie, str. M. Kogălniceanu, 1, Cluj-Napoca, 3400

2 Universitatea Babeş-Bolyai, Institutul de Gemologie, str. Avram lancu, 11, Cluj-Napoca, 3400

${ }^{3}$ Mârza, I., Ghiurcă, V., Bedelean, I., Lucreția Ghergari, Nicolescu, Şt., Valaczkay, T. (1991). Studiul geologic al formațiunilor purtătoare de pietre semiprețioase din Transilvania (Etapa a II-a). Județele: Alba, Hunedoara şi ariile limitrofe din județele Timiş. Contract nr. 87/1989. Catedra Geol.-Min., Univ. Babeş-Bolyai, Cluj-Napoca. - nepublicat 
Regiunea cercetată se încadrează Munților Metaliferi şi cuprinde Transilvanidele (Săndulescu, 1984), respectiv următoarele unități geostructurale (Balintoni, 1997): pânza de Căpâlnaş-Techereu, unitatea de Curechiu-Stănija, unitatea de Căbeşti şi unitatea de Bejan. Unitățile de pânză alcătuite din ofiolite şi sedimentar mezozoic asociat sunt dislocate în tectogeneza austrică şi reluate de mişcările laramice. Posttectonic s-au depus formațiuni sedimentare paleogene şi neogene (Badenian) păstrate sub formă de petice.

Interes gemologic major prezintă complexul ofiolitic (mezozoic) dezvoltat în mai multe sectoare (Hărțăgani, Luncoiu de Sus şi Luncoiu de Jos, Vălişoara-Băița) şi gheizeritele (badeniene) de la Sanatoriu (Brad).

Ofiolitele de tip arc (Cioflica et al., 1981) din zona Mureşului aparțin la trei serii magmatice: tholeiitice, calco-alcaline şi spilitice. În cadrul ofiolitelor din regiunea cercetată predomină, conform observațiilor noastre, următorii termeni petrografici: bazalte, bazalte cu olivin, bazalte amigdaloide, andezite bazaltice, andezite cu hornblendă şi biotit, microdolerite, dolerite şi brecii vulcanice (bazaltice şi andezitice) corespunzătoare manifestărilor explozive.

Vulcanitele neogene din regiunea Hărțăgani sunt importante pentru remobilizările de $\mathrm{SiO}_{2}$, angajate în procesele de hidrotermalism asupra ofiolitelor din acest perimetru.

\section{Consideratii petrografice}

Rocile complexului ofiolitic sunt de regulă alterate în diferite grade; transformări mineralogice importante suportă breciile vulcanice (piroclastitele) uşor penetrate de circulația soluțiilor hipogene şi exogene, datorită gradului ridicat de porozitate, precum şi efuziunile vulcanice marcate de importante goluri (alveole) de degazeificare submersă. Sunt relativ proaspete dyke-urile de roci bazice - frecvent dolerite, microdolerite - ce străbat suita depozitelor vulcanice-vulcanoclastice.

Modul de prezentare a silicei, respectiv în spații libere (pori, alveole de degazeificare, goluri de dizolvare, fisuri, fracturi, depuneri în jurul fragmentelor de brecii vulcanice, tectonice) şi metasomatic, substituind componenții minerali primari şi pasta rocii (vitroasă, hialopilitică, pilotaxitică), sugerează mecanismul genetic.

În cele ce urmează vom prezenta succint natura petrografică a rocilor ofiolitice şi relația cu procesul, respectiv natura silicifierii din perimetrul investigat.

Bazaltele - realizează nivele efuzive submerse, de grosimi variabile, în cadrul complexelor ofiolitice (Vălişoara, Podele etc.). Sunt roci de culoare cenuşie spre neagră, traversate de fisuri umplute cu depuneri peliculare de zeoliți albi sidefoşi sau roşiateci. Cele mai comune specii de zeoliți sunt: stilbit, mezolit, heulandit, subordonat analcim, laumontit, diabasit, hamsonit, natrolit etc. (Bedelean şi Stoici, 1984). Pentru unele ocurențe sunt caracteristice 
alveole-microalveole umplute cu calcit, zeoliți şi uneori cu calcedonie şi cuarț secundar. Bazaltele sunt roci afanitice cu textură fluidală şi subfluidală; pasta vitroasă (cca $45 \%$ ) înțesată cu microlite de plagioclazi (cca $32 \%$ ), mai conține microgranule de magnetit şi pirit $(0,30 \mathrm{~mm} \varnothing)$. Fenocristalele sunt reprezentate prin plagioclazi şi piroxeni, rar biotit.

Asociația mineralelor epigenetice $(<10 \%)$ revine zeoliților, calcitului, cloritului, cuarțului microgranular şi microfibros, mineralelor argiloase (formate pe seama plagioclazilor) şi hidroxizilor de fier.

Bazalte olivinice au culoare neagră şi evidențiază macroscopic, frecvente, microsferule secundare (verzi) de clorit, uneori alveole mai dezvoltate $(<3 \mathrm{~mm} \varnothing)$ umplute cu zeoliți (culoare brun roşcată). Microscopic se remarcă structura microporfirică şi textura subfluidală. Pasta rocii se compune din microlite de plagioclazi $(0,05-0,22 \mathrm{~mm})$ şi sticlă vulcanică, în care se află cristale mai dezvoltate de plagioclazi $(0,33-3,0 \mathrm{~mm})$ şi olivin $(0,10-0,54 \mathrm{~mm})$ pseudomorfozat de minerale serpentinice. Plagioclazii faneritici (maclați polisintetic) sunt intens fisurați şi transformați parțial în albit (nervuri albitizate) şi minerale argiloase, clorite.

Alterarea pastei rocii, a sticlei îndeosebi, suportă transformări în clorite (cca $20 \%$ din masa rocii); cloritul apare şi în alveole microsferulitice $(0,50-3,5 \mathrm{~mm} \varnothing)$ cu manşon marginal (cca 0,25 mm) de serpofit (culoare brun-verzuie, aproape izotrop). Angajarea integrală a rocii în procese de transformări secundare semnifică un mediu intens hidratat cu aciditate medie spre pronunțată.

Bazalte amigdaloide (PI. I, fig. 1) - au fost întâlnite în majoritatea zonelor cu ofiolite investigate (văile, Vălişoara, Câinet, Orăzii; perimetrele Băița, Hărțăgani etc.). Studiul microscopic al bazaltelor amigdaloide evidențiază structura afanitică şi textura subfluidală a pastei compuse din sticlă vulcanică de culoare brunie-feruginoasă, intens diagenizată respectiv substituită cu cuarț microcristalin, clorit, calcit microgranular şi hidroxizi de fier. Pasta rocii conține microlite de plagioclazi $(0,007 \times 0,07-0,04 \times 0,25$ $\mathrm{mm})$ parțial argilizați, subordonat microlite de piroxeni $(0,05 \times 0,10 \mathrm{~mm})$ şi de hornblendă, în cea mai mare parte oxidate şi calcitizate. Fanerite de plagioclazi $(0,70 \times 1,50 \mathrm{~mm})$ apar rar şi suportă o illitizare intensă. În cazul cristalelor mai proaspete se recunoaşte albitizarea (spilitizarea).

Alveolele secundare sunt preponderent umplute cu calcit, calcitclorit şi eventual silice. Calcitul sferolitic prezintă microtextură fibroradială (tip evantai, sau centrat); impregnarea cu hidroxizi de fier conferă calcitului culoare roşiatică. Filonaşe $(0,10 \mathrm{~mm})$, reprezentând o generație mai tânără de calcit, traversează uneori amigdalele. Bazaltele cu conținut important de amigdaloide calcitice nu prezintă premisele concentrațiilor de silicolite geme (secundare). Analiza unor eşantioane de pe valea Orăzii (localitatea Crăciuneşti) ne-a condus la separarea varietății de bazalte microamigdaloide. 
Andezite bazaltoide cu olivin şi piroxeni - caracterizează o parte a complexului ofiolitic din perimetrul localității Hărțăgani; sunt roci de culoare cenuşie sau neagră cu structură microporfirică, cu pasta hialopilitică, microlitele corespunzând plagioclazilor proaspeți $(0,008 \times 0,08 \mathrm{~mm}-0,08 \times 0,30 \mathrm{~mm})$. Faneritele sunt reprezentate de plagioclazi $(0,20 \times 0,35-0,65 \times 1,5 \mathrm{~mm})$, clinopiroxeni $(0,80 \times 2,5 \mathrm{~mm}$, cristalele mai dezvoltate). Olivinul $(0,30 \times 0,60 \mathrm{~mm})$ este total pseudomorfozat cu minerale serpentinice. Pe fisuri şi în alveole alungite-eliptice ( $1-2 \times 3 \mathrm{~cm}$, cele mai dezvoltate) s-a depus calcedonie cu structură sferolitică-fibroasă şi uneori cuarț microgranular.

Andezite cu hornblendă şi biotit - au fost identificate în masa complexului ofiolitic din perimetrul localității Luncoiu de Jos. Roca are culoare cenuşie-verzuie şi structură porfirică, realizată de fanerite de plagioclazi $(0,50 \times 0,70-1,50 \times 2,00 \mathrm{~mm})$, hornblendă $(<2,0 \mathrm{~mm})$, biotit $(0,30 \times$ $0,80 \mathrm{~mm})$ şi microlite de plagioclazi $(0,008 \times 0,08 \mathrm{~mm})$. O însemnată parte din pasta hialopilitică este zeolitizată.

Microdolerite - (PI. I, fig. 2) filoniene (în general, sub $1 \mathrm{~m}$ grosime) traversează suita ofiolitelor efuzive şi piroclastice, spre ex., în versantul stâng al văii Vălişoara (în amonte de localitate).

Observațiile microscopice relevă structura microholocristalină (microdoleritică) realizată de microlite $(0,04 \times 0,15 \mathrm{~mm})$ de plagioclazi bazici cu dispunere intersertală, microlite de piroxeni, aproape izometrici $(0,08 x$ $\mathrm{mm} \varnothing)$ şi o generație porfirică reprezentată de plagioclazi $(0,50 \times 1,0 \mathrm{~mm})$ frecvent albitizați marginal. Local se observă zeolitizarea, calcitizarea şi silicifierea rocii, noduli de zeoliți, calcit şi cuarț microcristalin-fibros $(0,50 x$ $0,80 \mathrm{~mm}$ ).

Dolerite - s-au identificat în cuprinsul complexului ofiolitic din valea Câinet (Crăciuneşti). Roca holocristalină cu structură doleritică conține în principal, plagioclazi proaspeți $(0,60 \times 1,8 \mathrm{~mm})$, augit $(0,30 \times 0,50 \mathrm{~mm})$, hornblendă brună $(0,10 \times 0,20-0,40 \times 1,80 \mathrm{~mm})$. Componenții accesorii sunt reprezentați prin microgranule de magnetit-ilmenit $(<4 \%)$.

Brecii piroclastice - se asociază spațial complexelor ofiolitice sub forma unor nivele de grosimea metrilor sau zecilor de metri. Vulcanolitoclastele din breciile piroclastice de la Podeni şi Crăciuneşti (valea Câinet), prezintă compoziție variabilă, de la bazalte la andezite bazaltice; în unele cazuri s-a remarcat textura variolitică (PI. II fig. 3). Plagioclazii (andezin bazic/labrador) şi piroxenii sunt proaspeți, în schimb olivinul este integral serpentinizat. Atât plagioclazii cât şi piroxenii se dispun glomeruliform (insular).

Pe cale secundară se remarcă concentrații de silice (pe fisuri, în goluri, în jurul vulcanolitoclastelor). Împreună cu silicea apare clorit, calcit şi adesea epidot. 
MINERALE GEME ASOCIATE GENETIC OFIOLITELOR MEZOZOICE ŞI GHEIZERITELOR ...

\section{Perimetre de interes gemologic}

În regiunea investigată s-au separat cinci perimetre, între care unele cu importanță gemologică certă, ceea ce se va remarca în continuare.

\section{Perimetrul Valea Luncoiu - Valea Lungă}

Din punct de vedere geologic perimetrul este alcătuit din roci ofiolitice mezozoice, andezite neogene şi pietrişuri (de Almaşu Mare) de vârstă badeniană. În aluviunile văii, alături de fragmente de roci ofiolitice, apar sporadic fragmente de cuarț microcristalin de culoare cenuşie deschisă, cenuşie închisă şi cenuşie roşiatică; dimensiunile acestora ating 10-15 cm mărime; ele reprezintă fragmente de cuarț filonian de origine hidrotermală, marcate de fisuri transversale şi mai rar longitudinale, umplute şi ele cu cuarț.

Silicolitele hidrotermale sunt neomogene sub aspect structuraltextural, în sensul că se compun din zone izometrice $(0,5-1,0 \mathrm{~mm})$, paralele sau eliptice $(0,80 \times 2,5 \mathrm{~mm})$, cu microtextura masivă, respectiv concentrică, fiind constituite din cuarț microgranular şi cuarț microfibros. Această textură, de ansamblu, a rezultat prin substituția $\mathrm{cu} \mathrm{SiO}_{2}$ a fragmentelor unei brecii vulcanice, iar partea cementativă s-a depus direct din soluții în spațiile libere dintre fragmente (PI. II, fig. 4, PI. III, fig. 5). În afara acestui argument de ordin structural-textural privind substituția, drept mărturie sunt aduse sporadicele relicte de plagioclazi prezente în silicolite. Asociat cuarțului secundar (microcristalin şi fibroradiar) se află subordonat, calcit şi granule de epidot.

În Valea Luncoiu se identifică rar fragmente de calcedonie nodulară şi agatiformă, cu originea în complexul ofiolitic. Culoarea acesteia este cenuşie, cenuşie slab albăstruie; textura este compactă, iar dimensiunile fragmentelor identificate rar depăşesc $10 \mathrm{~cm}$. Importanța gemologică a perimetrului descris este minoră.

\section{Perimetrul Valea Vălişoara - Valea Orăzii}

Perimetrul este plasat în cea mai mare parte în complexul ofiolitic mezozoic, la care se adaugă calcare cretacice şi pietrişuri de Almaşu Mare (badeniene). Văile conțin aluviuni heterogene sub aspect petrografic, preponderent de natură ofiolitică. În aluviuni apar foarte rar fragmente mici de cuarț cenuşiu, provenit din ofiolite.

Eşantioanele de cuarț cenuşiu-feruginos au textură spongioasă dezvoltată în urma dizolvării şi levigării sulfurilor (pirit). La microscop, cuarțul prezintă zone cu grade diferite de cristalizare: de la cuarț heterogranular $(0,65 \times 1,0 \mathrm{~mm})$, la cuarț microgranular. Cuarțul microgranular prezintă tendința dispunerii sub formă de rozete concentrice-radiare (PI. III, Fig. 6), granulele componente manifestând extincție longitudinală. Impregnarea cu 
hidroxizi de fier - uneori o masă goethitică de peste $50 \%$ - se remarcă frecvent. Filonaşe submilimetrice umplute cu cuarț microgranular, şi mai rar cu cuarț fibros (calcedonie), depuse într-o etapă târzie (cel puțin două generații), străbat frecvent ofiolitele.

În cazul unor eşantioane se observă substituția rocii cu silice în care se remarcă relicte de feldspați plagioclazi şi hornblendă (trecută în biotit şi hidroxizi de fier). Cuarțul din zona axială a filoanelor este mai curat şi prezintă structură microgranulară. Rareori apar fisuri umplute cu o generație secundară de cuarț, în zona axială a acestora aflându-se hidroxizii de fier.

În aluviunile văii Orăzii s-au găsit eşantioane de calcare silicifiate, compacte, de culoare cenuşie, cu structura microgranulară. Microscopul surprinde compoziția mineralogică şi structura unui calcar micritic (peletalpeletoid) cu rare resturi de spongieri: secțiuni transversale $(0,15 \mathrm{~mm})$ şi longitudinale $(0,06 \times 1,30 \mathrm{~mm})$. Resturile de spongieri sunt constituiți din cuarț microfibroradiar (PI. IV, fig. 7). Întreaga masă a rocii este silicifiată în grade diferite (cca 10-35\%), sursa silicei fiind de origine biogenă.

Perspectivele acestui sector nu sunt încurajatoare sub aspect gemologic. Totuşi se întâlnesc sporadic fragmente de cuarț masiv microgranular, dispus filonian, sub $5 \mathrm{~cm}$ grosime, care microscopic prezintă structură în rozetă.

\section{Perimetrul Cheile Băița-Crăciuneşti}

Din punct de vedere geologic perimetrul este alcătuit din magmatite ofiolitice mezozoice (în general piroclastite), peste care stau în poziție tectonică calcare recifale de vârstă jurasică. În jurul localității Băița sunt prezente şi nisipurile-pietrişurile de Almaşu Mare, de vârstă badeniană.

Pe valea Câinet, precum şi pe un torent din Pădurea lui Cornel (la Crăciuneşti), apar jaspuri roşii asociate ofiolitelor. În secțiuni microscopice se remarcă o masă de hidroxizi şi oxi-hidroxizi de fier (hematit, goethit), traversată de fisuri submicronice (două generații) umplute cu silice microcristalină; uneori se recunosc fisuri neregulate de deshidratare, mineralizate cu cuarț microcristalin (PI. IV fig. 8). Valoarea gemologică a jaspurilor identificate impune cercetări mai de amănunt în zonă.

\section{Perimetrul Hărțăgani}

Cercetările efectuate în perimetrul Hărțăgani s-au dovedit deosebit de încurajatoare, pe baza probelor recoltate din aluviunile văii Cordurea. Trei văi principale confluează în apropierea localității Hărțăgani: valea Duba la est (străbate sedimentar badenian, respectiv complexul pietrişurilor de Almaşu Mare, inclusiv andezite cuarțifere aparținătoare ciclului II de erupții neogene), valea Cordurea (la mijloc) şi valea Racăş (în vest). Toate aceste văi străbat roci ale complexului ofiolitic intrus de corpuri subvulcanice de andezite cuarțifere cu amfiboli şi biotit (bazinul văii Cordurea) şi andezite amfibolice de tip Fața Băii (vf. Bulzu, în valea Racăş). 
Aluviunile ambelor văi (Cordurea şi Racăş) conțin fragmente de silicolite, mai precis fragmente de ofiolite traversate de filonaşe cu calcedonie şi cuarț; frecvența însemnată a acestor eşantioane şi originea hidrotermală conduc la ideea unei relații genetice între activitatea hidrotermală asociată magmatitelor neogene şi ofiolite, care în multe situații ar reprezenta roca suport hidrotermalizată (mineralizată).

În acest perimetru s-a identificat:

- Cuarț microgranular dispus sub formă de filonaşe-filoane în roci ofiolitice; grosimea acestora este de ordinul centimetrilor $(<5 \mathrm{~cm})$ şi se dispun, de regulă, paralel între ele; mai rar se observă silice masivă (nodulară) de culoare cenuşie neomogenă cu microstructură fibroasă (PI. V, fig. 9).

- Silice masivă de culoare cenuşie, cu aspect pătat, rezultat prin repartiția zonală şi neomogenă a intensității culorii cenuşii. $\mathrm{Pe}$ alocuri silicea conține microalveole. Spărtura este neregulată, concoidală. Studiul microscopic relevă următoarele aspecte: silicea de culoare intens cenuşie corespunde varietății amorfe, iar cea cenuşie varietății microgranulare formate prin recristalizarea primei varietăți. În urma recristalizării şi remobilizării silicei apar zone cu structură fibro-radiară în centrul cărora se remarcă, adesea, cuarț microgranular. Fisuri submilimetrice umplute cu silice de terță generație care străbat masa silicolitului apar rar.

- Filonaşe de cuarț de culoare albă cu textură în benzi (prinse în masa andezitelor piroxenice), asociate cu carbonați şi uneori cu epidot şi zeoliți. Mineralizația filoniană a andezitelor piroxenice se compune din agregate microgranulare de calcit, însoțite de cuarț microgranular, dispuse sub formă de venule în masa carbonatică. Sporadic apar fragmente de rocă şi cristale individuale de plagioclazi etc., în silicea compactă. Piroxenii sunt calcitizați marginal şi pe fisuri; local calcitul este substituit de cuarț.

- Filonaşe de cuarț cenuşiu slab verzui $(3,5 \mathrm{~cm}$ grosime) prinse în andezite se observă frecvent în aluviunile văii Cordurea de la Hărțăgani. La microscop roca gazdă se dovedeşte a fi un andezit hipabisic cu textură fluidală. Zona de contact cu roca este formată din benzi de calcit microgranular în care se află sporadic granule de epidot, rezultat în procesul de reacție (aport de calciu) cauzat de soluțiile hidrotermale. Spre interiorul filonului se dezvoltă în continuare o bandă de grosime redusă (cca $0,5 \mathrm{~cm}$ ) constituită din cuarț microgranular în amestec cu calcit, după care se dezvoltă o zonă de cuarț microgranular traversat de vinişoare de calcit, local calcit şi epidot. Analiza microscopică a filoanelor asociate andezitelor piroxenice sugerează următorul proces: soluțiile hidrotermale bogate în $\mathrm{SiO}_{2} \mathrm{~s}-\mathrm{au}$ depus pe fracturi, ulterior fiind mineralizate cu calcit (PI. V, fig. 10). În procesul de reacție carbonat-silice s-a format epidot în zona marginală, remobilizat ulterior împreună cu calcitul pe fisurile din masa silicei. 
Varietățile de cuarț fibros roşiatec (tip carneol), asociat cu cuarț alb, remarcate în acest perimetru, prezintă interes gemologic major, ca şi concrețiunile de silice $(<5 \mathrm{~cm} \varnothing)$ întâlnite, deocamdată, numai în aluviuni (valea Cordurea, Hărțăgani). Asociat ofiolitelor din regiune se află şi varietăți de opal.

\section{Perimetrul Brad}

Silicolitele sunt asociate genetic complexului ofiolitic, vulcanitelor neogene şi efectului hidrotermal al acestora asupra ofiolitelor. Ocurențe cu silicolite se află în zonele: Curechiu-Buceş, Bucureşci-Rovina, Bazna-Valea Arsului-Musariu, Crişcior etc. Cele mai interesante, unicat la noi în țară, sunt gheizeritele policrome din vecinătatea Bradului.

În dealul Măgura Bradului (La Sanatoriu) sunt menționate din secolele trecute produse silicioase policrome, atribuite ulterior activități gheizeriene asociate vulcanismului neogen din regiune (Ghițulescu et al., 1968; Ghiurcă, 1981; Ghergari, lonescu, 1999, Ghrgari et al., 1999). Depunerea soluțiilor silicioase (epitermale) a avut loc în mici bazinete limnice, dovada constituind-o resturile de moluşte şi de plante de baltă încorporate în silice şi substituite cu $\mathrm{SiO}_{2}$. Mediul bogat în hidroxizi de fier şi mangan cu distribuție spațială inegală a provocat o largă variație cromatică gheizeritelor, între care predomină varietățile de ocru şi roşu cu diferite nuanțe, cenuşii sau negre; rar se întâlneşte o varietate verzuie.

Mineralogia acestor gheizerite a fost detaliată de Ghergari şi lonescu (1999), care evidențiază pe lângă cuarț microcristalin şi fibros, opal, cristobalit/ tridimit.

Gradul avansat de fisurare a gheizeritelor policrome de la Brad permite doar confecționarea unor piese mici de geme, dar, cu calități estetice remarcabile.

\section{Concluzii}

În regiunea cercetată s-au conturat cinci perimetre cu silicolite geme. Valoarea economică a substanțelor minerale identificate constă în calitățile tehnice (duritate, grad de lustruire) şi estetice (culoare, microtexturi şi structuri, incluziuni). Ocurențe mai importante sunt cele din perimetrele Hărțăgani şi Brad.

Între gemele fine menționate, importanță economică manifestă: calcedoniile filoniene şi concreționare de la Hărțăgani, gheizeritele policrome de la Brad, jaspurile roşii din sectorul Cheile Băița, precum şi unele apariții de silicolite geme din sectoarele văilor Luncoiu şi Câinet, Curechiu-Buceş.

Prelucrarea acestor silicolite sub formă de geme cu geometrie diferită se pretează în calitate de piatră montată în inele, brățări, cercei, butoni, brelocuri, mărgele etc.; totodată se pot confecționa obiecte de artă pentru interioare, deosebit de spectaculoase. 
MINERALE GEME ASOCIATE GENETIC OFIOLITELOR MEZOZOICE ŞI GHEIZERITELOR ...

\section{BIBLIOGRAFIE}

1. Balintoni, I. (1997). Geotectonica terenurilor metamorfice din România. Impr. Univ. Babeş-Bolyai, 241 p., Cluj-Napoca.

2. Bedelean, I., Stoici, S.D. (1984). Zeoliții. Ed. Tehnică, 227 p., Bucureşti.

3. Cioflica, G., Savu, H., Nicolae, I., Lupu, M, Vlad, Ş. (1981). Alpine Ophyolitic Complexes in South Carpatians and South Apuseni Mountains (Guide Exc. A. 3). Carp. Balk. Geol. An XII, Congr. Inst. Geol.-Geophys, 18, Bucureşti.

4. Ghițulescu, T.P., Verdeş, Gr., Chința, R. (1968). Zăcămintele de silicolite din bazinul neogen al Bradului (jud. Hunedoara). Stud. Cerc. Geol.-Geofiz.-Geogr., Ser. Geol., 13/1, 67-76, Bucureşti.

5. Ghiurcă, V. (1981). Câteva date geologice asupra silicolitelor semiprețioase din jud. Hunedoara. Studia Univ. Babeş-Bolyai (Geol.-Geogr.), XXVI/1, 42-47, ClujNapoca.

6. Ghergari, Lucreția, lonescu Corina (1999). Genetic considerations on jasper în the Brad area (Apuseni Mts., Romania). Anal. Univ. Bucureşti, Min., Petr., Metallogeny and Geoch. Intern. Sympos (Abstract volume), XLVIII, p. 32.

7. Ghergari, Lucretia, lonescu Corina, Püspöki, Zs. (1999). Jaspis occurrence from Brad, Apuseni Mts. (Romania). Gems and Gemology, Fall 1999, Carlsbad Ca, SUA, p. 139-140.

8. Giuşcă, D., Cioflica G., Savu, H. (1963). Vulcanismul mezozoic din Masivul Drocea (Munții Apuseni). Asoc. Geol. Carp.-Balc. Congr., V, H., p. 31-44, Bucureşti.

9. Ianovici, V., Giuşcă, D., Ghițulescu T.P., Borcoş, M., Lupu, M., Bleahu, M., Savu, H. (1969). Evoluția geologică a Munților Apuseni, Ed. Acad R.S.R., 743 p. Bucureşti.

10. lanovici, V., Borcoş, M., Bleahu, M., Patrulius D., Lupu, M., Dimitrescu, R., Savu, H. (1976). Geologia Munților Apuseni, Ed. Acad R.S.R., 631 p. Bucureşti.

11. Mârza, I., Ghergari Lucreția, Lázlo, K. (1989). Liesegang structures (hydrothermalmetasomatic) in the pebbles of Badenian conglomerates from polymetallic ore deposit at Băiaga-Coranda (Homdol, the Metalliferous Mts.). Studia Univ. Babeş-Bolyai, Geol.-Geogr., XXXIV, 1, Cluj-Napoca, p. 87-96.

12. Savu, H. (1980) Genesis of the Alpine Cycle Ophiolites from Romania and Their Associated Calc-Alkaline and Alkaline Volcanics. An. Inst. Geol. Geophys., LVI, p. 55-57, Bucureşti.

13. Savu, H. (1983) Geotectonic and Magmatic Evolution of the Mureş zona (Apuseni Mountains)- Romania. An. Inst. Geol. Geophys., LXI, 253-262, Bucureşti

14. Săndulescu, M., (1984). Geotectonica României. Edit. Tehnică, 336 p., Bucureşti. 


\section{PLANŞA I}

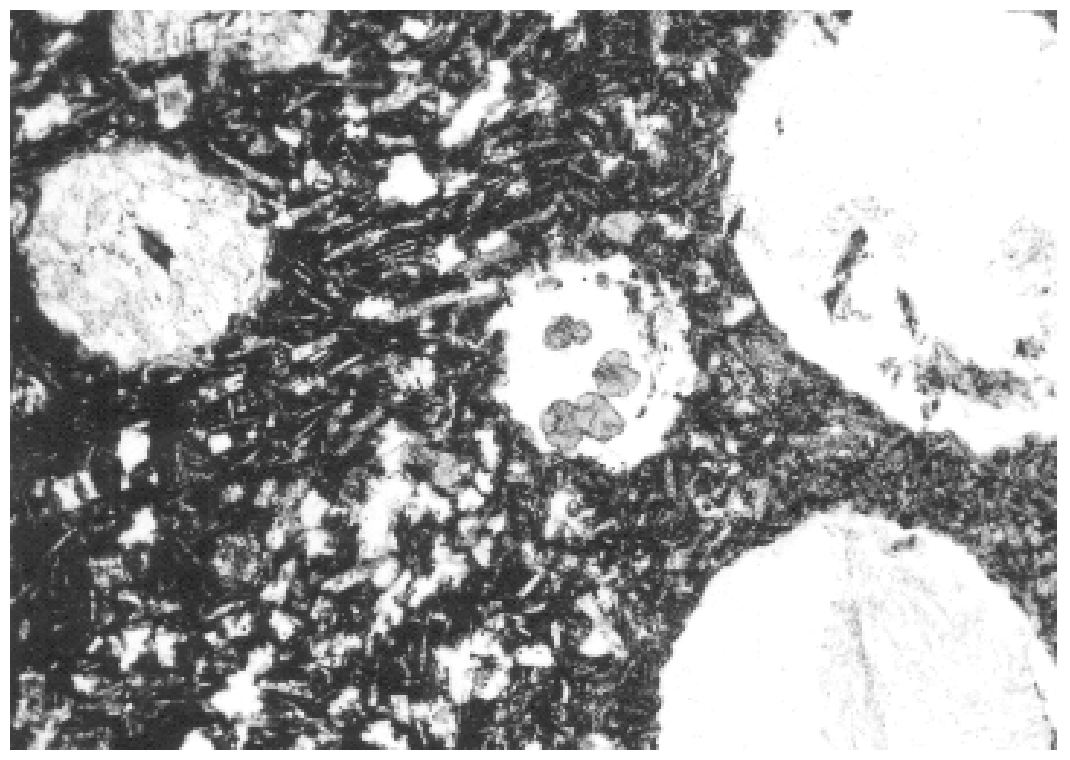

Fig. 1. Bazalt amigdaloid (Valea Câinet, torentul de la mină, Crăciuneşti). Sferolite de calcit microgranular (alb), conțin microrozete de clorit (negru). Pasta rocii evidențiază textură fluidală, marcată de orientarea microlitelor de feldspați. Microfotografie, $N+, 35 X$.

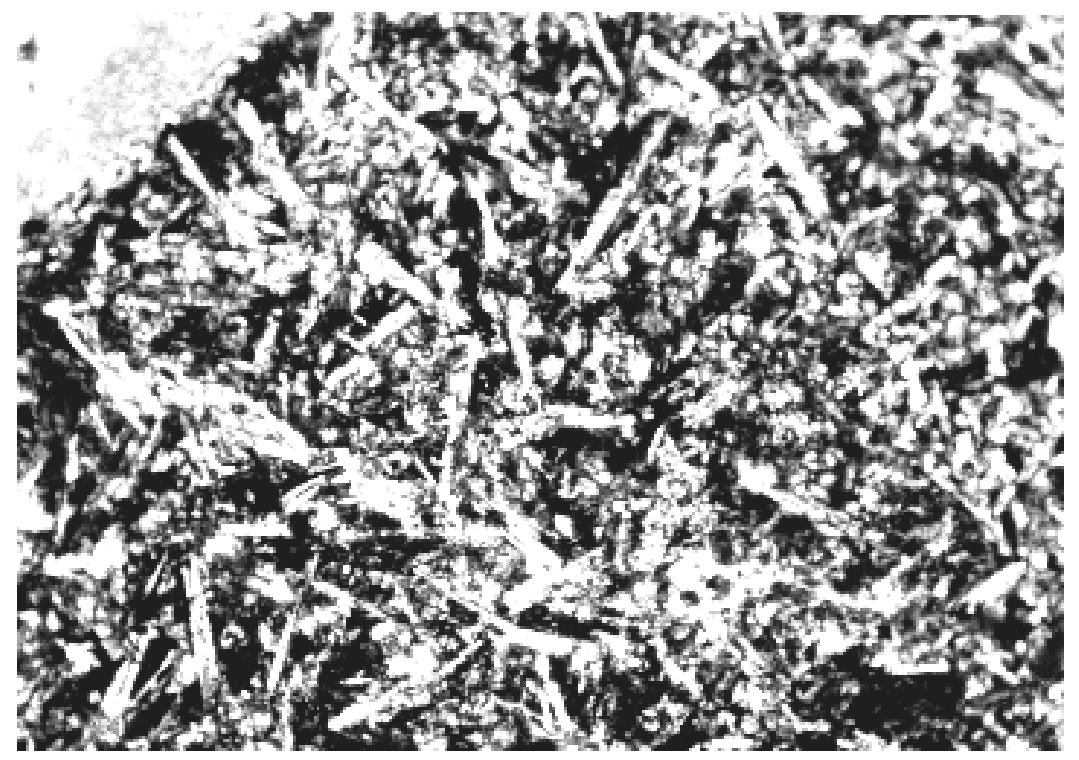

Fig. 2. Microdolerit (Valea Vălişoara, în amonte de localitatea Vălişoara); dyke, în vulcanite şi vulcanoclastite bazaltice. Se remarcă structura microholocristalină şi textura intersertală realizată de relația plagioclazi - microlite de piroxeni (granular). Microfotografie, $N+, 35 X$ 


\section{PLANŞA II}

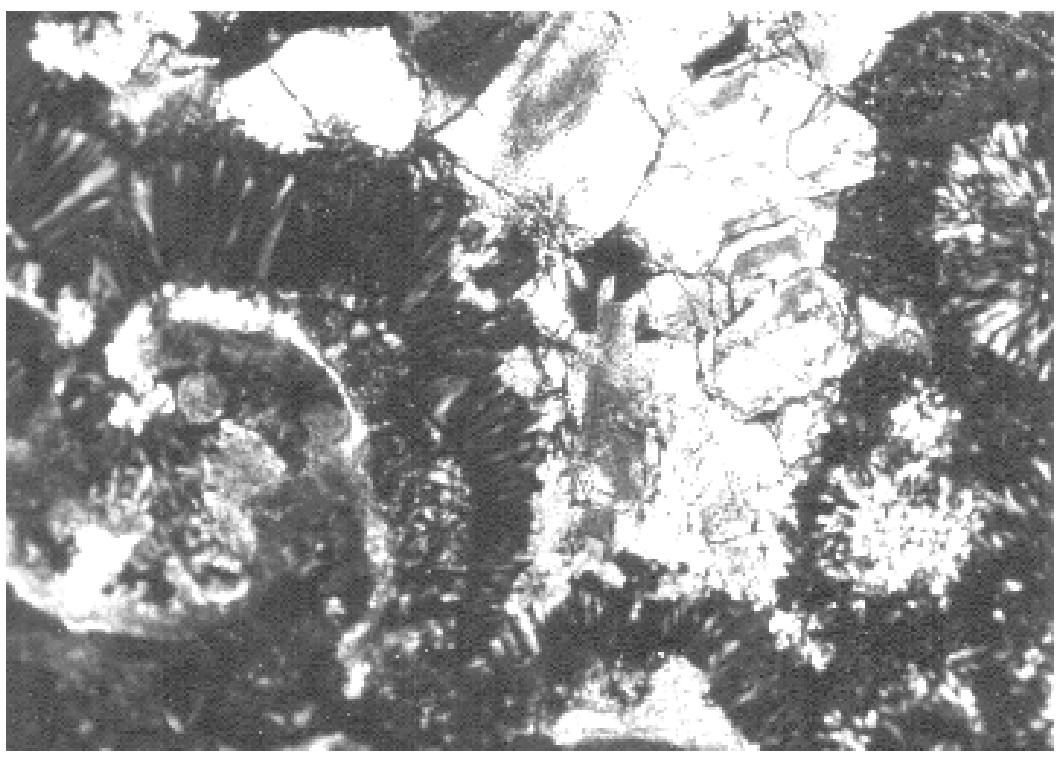

Fig. 3. Brecie piroclastică parțial silicifiată. Fragmente bazaltice cu textură variolitică, conturate de silice microfibroasă (culoare cenuşie deschisă), uneori în asociație cu cristale de epidot (granule). Podele. Microfotografie, $N+, 80 X$.

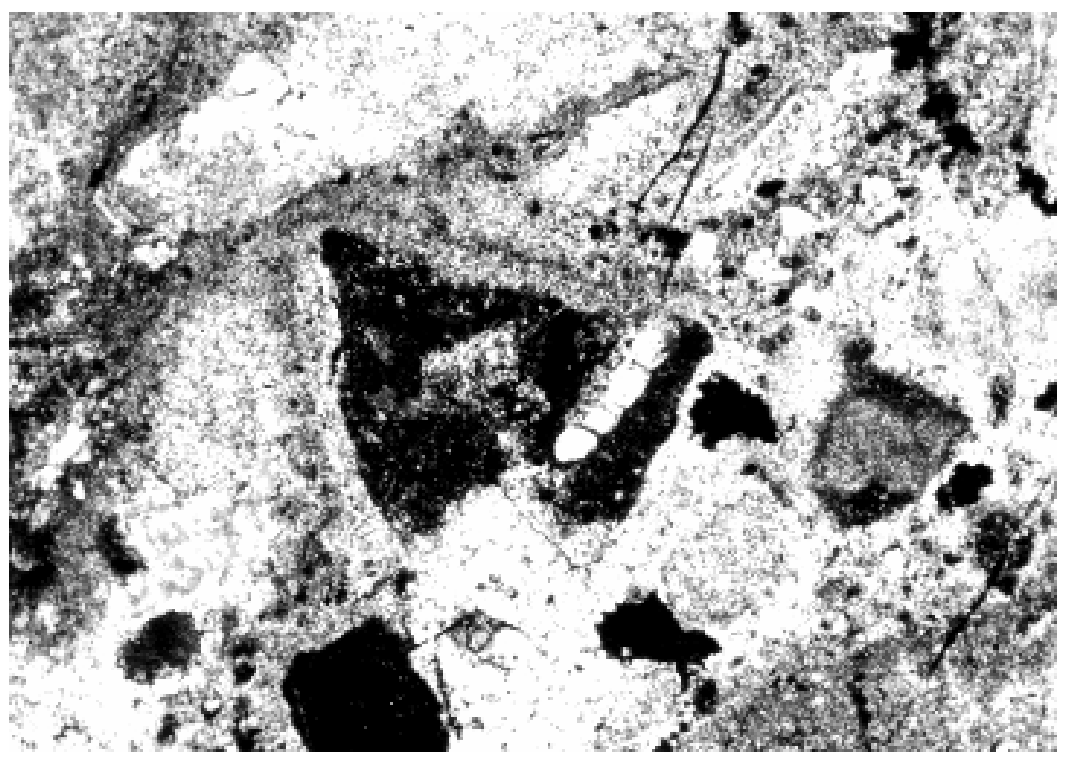

Fig. 4. Brecie vulcanică parțial silicifiată (Valea Lungă, la 1,5 km de confluență). Se observă silicifierea rocii piroclastice din care se conservă fragmente angulare parțial silicifiate (în centru un vulcanoclast cu apatit), şi total substituite cu silice (forma fragmentelor realizează doar o "umbră" a morfologiei angulare inițiale). Microfotografie, $N+, 35 X$. 


\section{PLANŞA III}

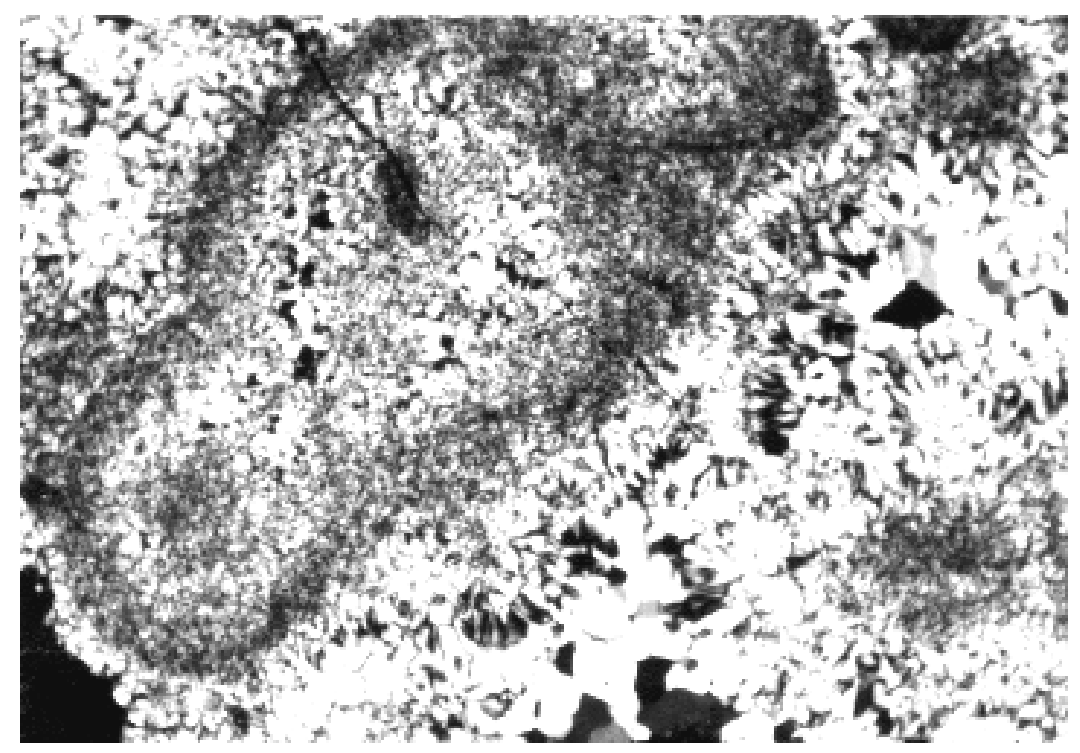

Fig. 5. Brecie vulcanică integral silicifiată (Valea Lungă, aluviuni). Vulcanoclastitele sunt total substituite cu cuarț cripto-microgranular, remarcându-se o zonalitate a mineralizării metasomatice cu $\mathrm{SiO}_{2}$. Cimentarea fragmentelor se realizează prin cuarț microcristalin de crustificație. Microfotografie, $N+, 35 X$.

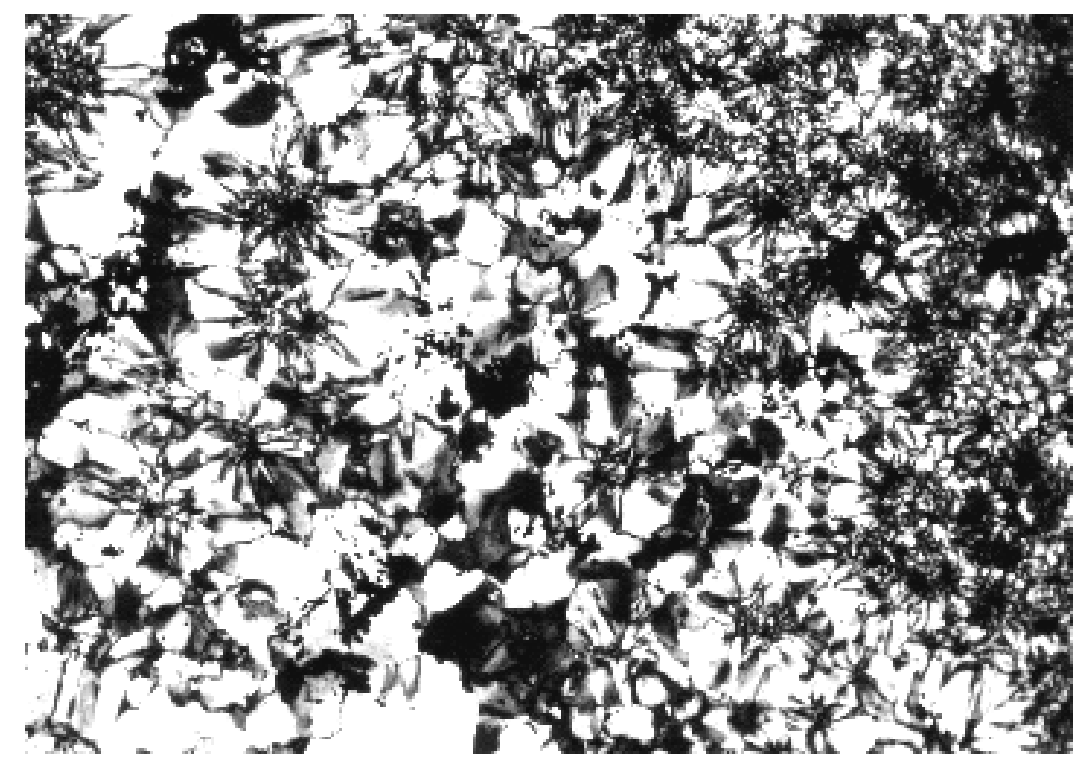

Fig. 6. Cuarț microcristalin şi microfibros dispus în rozetă (Valea Orăzii, Crăciuneşti). Microfotografie, $N+, 80 X$. 


\section{PLANŞA IV}

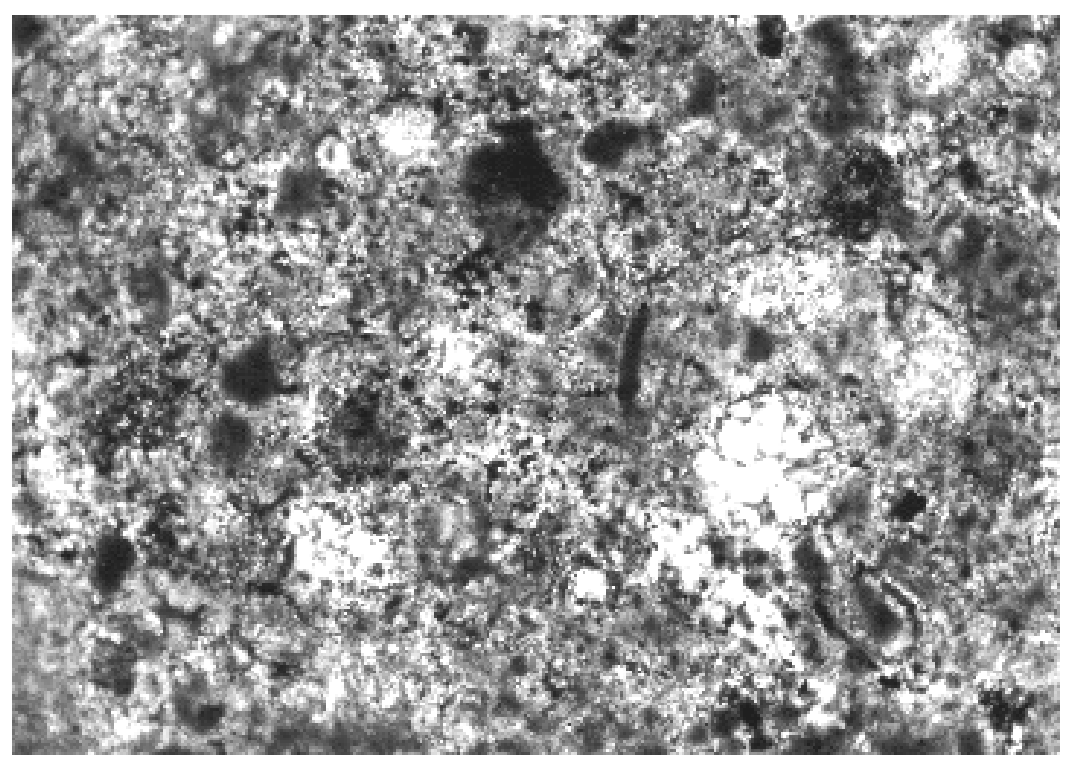

Fig. 7. Calcar mezozoic, peletal, silicifiat (Valea Orăzii, Crăciuneşti). Microscopul ilustrează silicifierea parțială în toată masa rocii şi constituția din silice microgranulară a radiolarilor.Microfotografie, $\mathrm{N}+, 100 \mathrm{X}$.

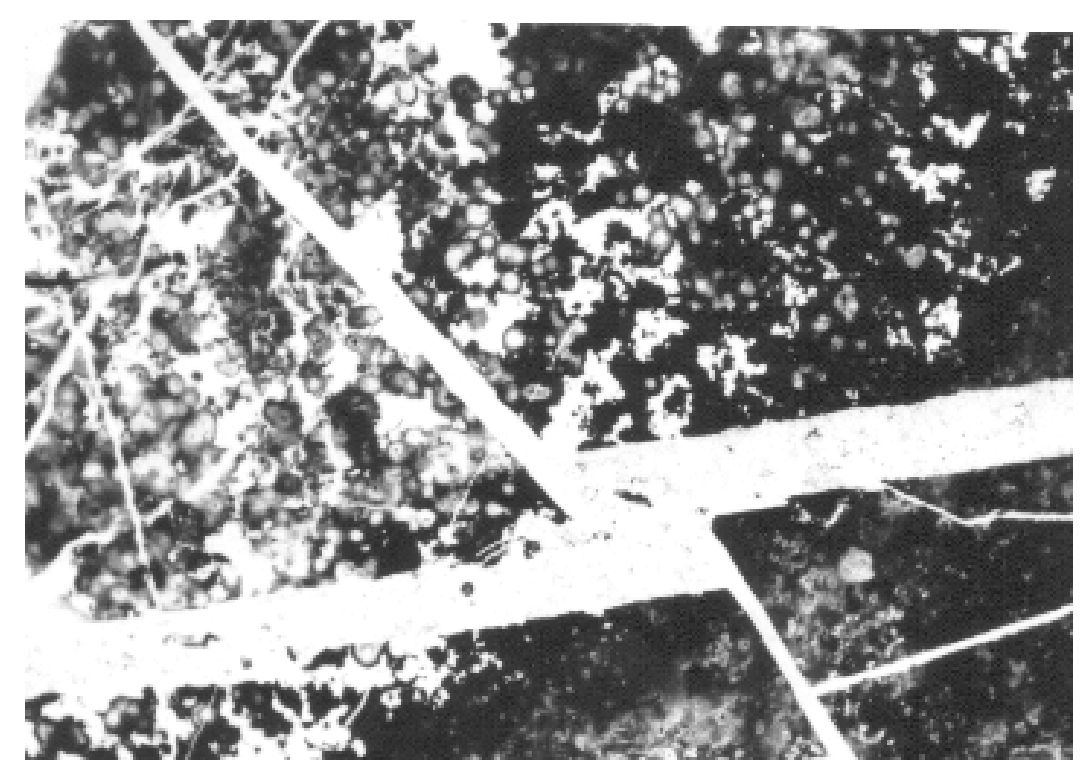

Fig. 8. Jasp feruginos - Cheile Băița, versantul stâng al văii Câinet, torentul din Pădurea lui Cornel - traversat de microfalii umplute de cuarț microgarnular. Microfotografie, $1 \mathrm{~N}, 35 \mathrm{X}$. 


\section{PLANŞA V}

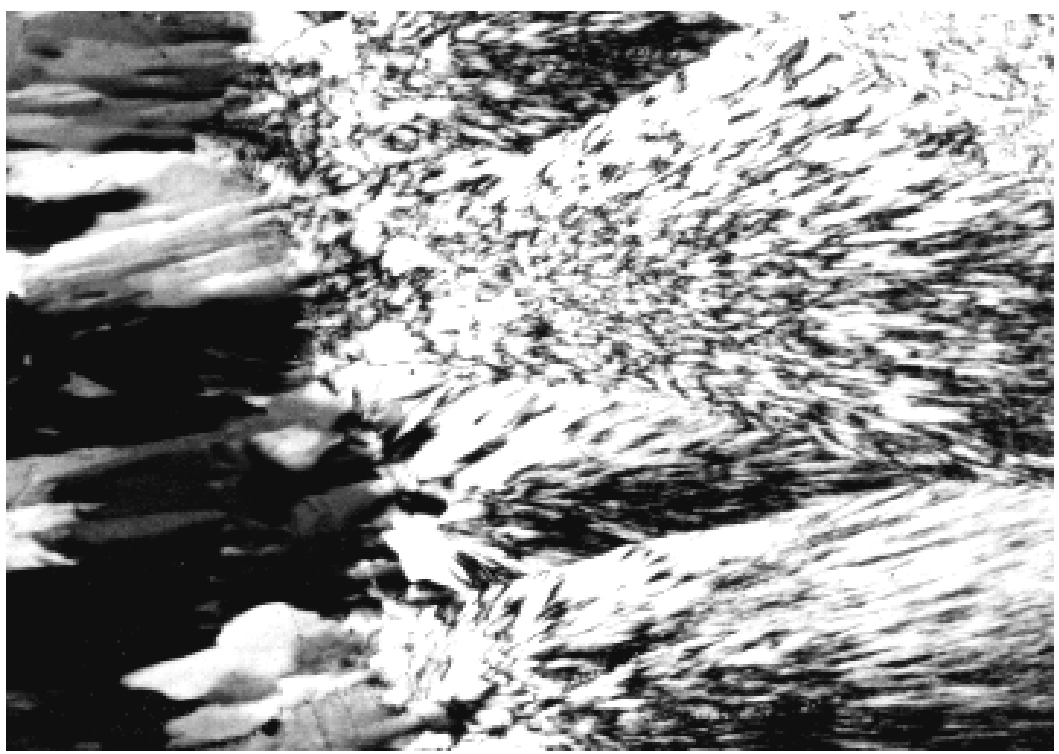

Fig. 9. Nodul de silice concreționară (fragment din aluviuni, Valea Cordurea, Hărțăgani). Zona marginală se compune din cuarț microgranular - alungit, şi cuarț microfibros dispus în evantai. Microfotografie, $N+, 35 X$

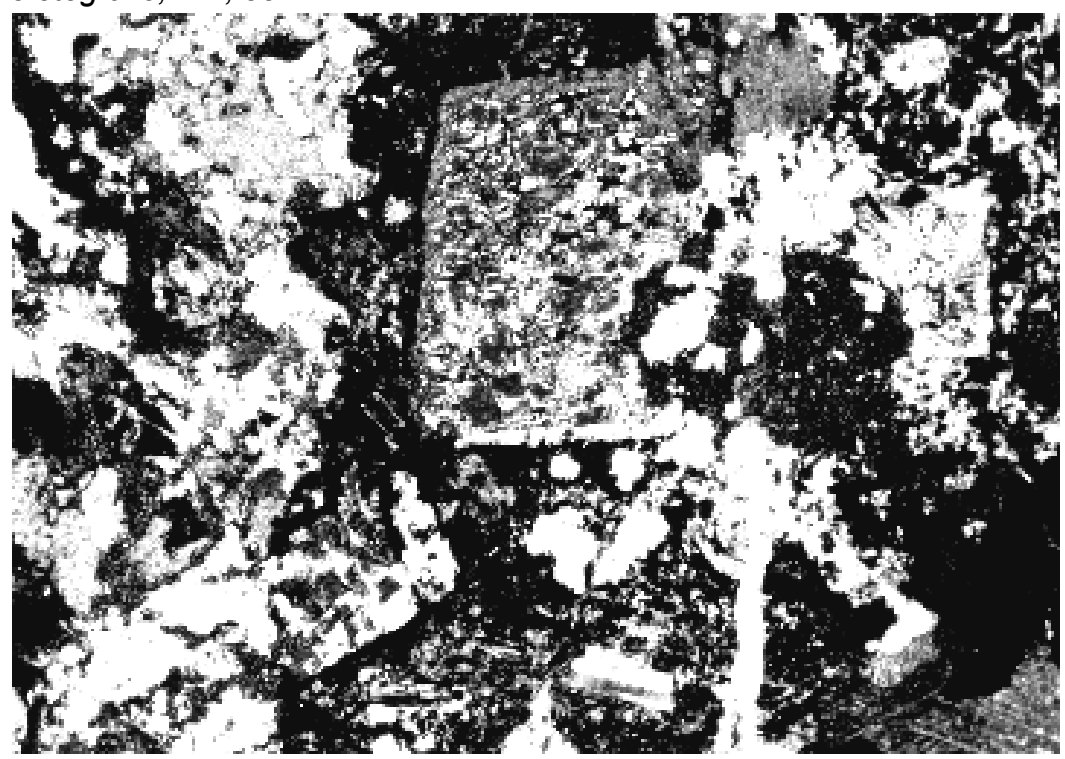

Fig. 10. Andezit piroxenic neogen silicifiat (Hărțăgani, Valea Cordurea). Microscopul ilustrează silicifierea mezostazei rocii, substituția incipientă şi aproape totală a piroxenilor cu cuarț microcristalin, umplerea fisurilor cu silice şi carbonați, apariția unei generații ulterioare de silice şi carbonați depuse pe fisuri. Microfotografie, $N+, 35 X$. 